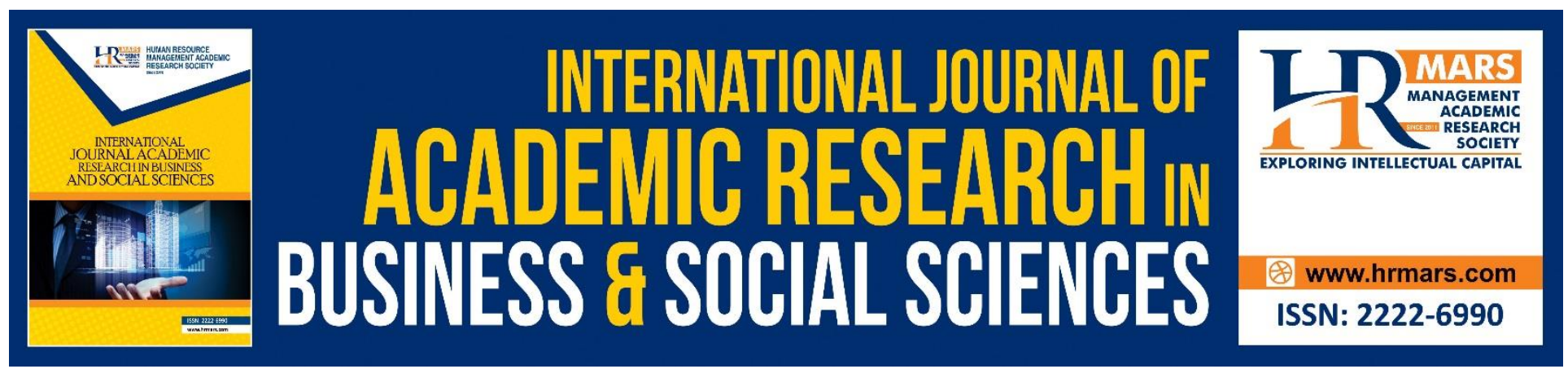

\title{
Similarities and Differences: A Preliminary Comparative Study of Arabic and Kadazandusun Phonology
}

\author{
Mohd Taqwudin Mohd Yazid \\ Veronica P. Atin
}

To Link this Article: http://dx.doi.org/10.6007/IJARBSS/v9-i2/5617

DOI: $10.6007 /$ IJARBSS/v9-i2/5617

Received: 12 Jan 2019, Revised: 19 Feb 2019, Accepted: 08 March 2019

Published Online: 10 March 2019

In-Text Citation: (Yazid \& Atin, 2019)

To Cite this Article: Yazid, M. T. M., \& Atin, V. P. (2019). Similarities and Differences: A Preliminary Comparative Study of Arabic and Kadazandusun Phonology. International Journal of Academic Research in Business and Social Sciences, 9(2), 804-817.

\section{Copyright: (C) 2019 The Author(s)}

Published by Human Resource Management Academic Research Society (www.hrmars.com)

This article is published under the Creative Commons Attribution (CC BY 4.0) license. Anyone may reproduce, distribute, translate and create derivative works of this article (for both commercial and non-commercial purposes), subject to full attribution to the original publication and authors. The full terms of this license may be seen

at: http://creativecommons.org/licences/by/4.0/legalcode

\section{Vol. 9, No. 2, 2019, Pg. 804 - 817}

Full Terms \& Conditions of access and use can be found at http://hrmars.com/index.php/pages/detail/publication-ethics 


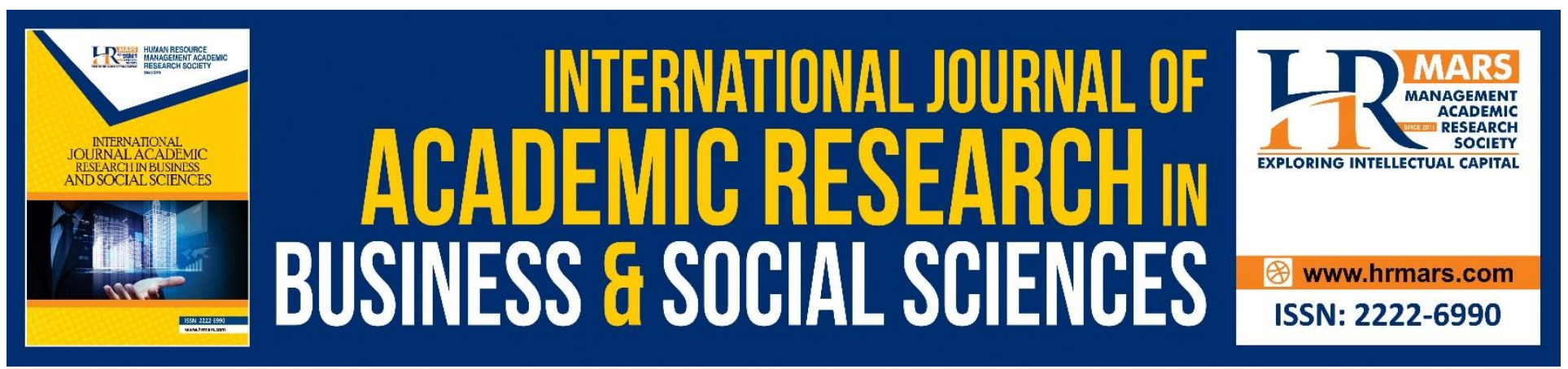

\title{
Similarities and Differences: A Preliminary Comparative Study of Arabic and Kadazandusun Phonology
}

\author{
Mohd Taqwudin Mohd Yazid \\ Centre for the Promotion of Knowledge and Language, Universiti Malaysia Sabah \\ Email: mohdtaqwudin@ums.edu.my \\ Veronica P. Atin \\ Centre for the Promotion of Knowledge and Language, Universiti Malaysia Sabah \\ Email:vpetrus@ums.edu.my
}

\begin{abstract}
Arabic is one of the languages that is offered as a foreign language to learners who have never learned the language before studying in UMS. Takers of the language include learners of the Kadazan/dusun ethnic groups who speak either any dialect of Kadazan/Dusun, Sabah Malay, or English as their first language. The study compares some phonological aspects of Arabic and Kadazandusun with the objectives of identifying the differences between the phonological systems of Arabic and Kadazandusun, and suggest how the differences might be affecting learners of Kadazandusun who learn Arabic as a foreign language. The findings show that Arabic and Kadazandusun share three similar vowels, but Arabic has twelve consonants that are different than Kadazandusun. Apart from that, in Arabic vowel alterations can carry grammatical functions such as plurality which do not exist in Kadazandusun. The authors suggest some areas of difficulties for Kadazandusun learners in learning Arabic, and recommended further studies to confirm the suggestions, as well as to propose learning strategies for learners to cope with the difficulties.
\end{abstract}

Keywords: Foreign language, Arabic, Kadazandusun, Phonology, Areas of Learning Difficulties

Introduction

Arabic and Kadazandusun are two languages offered as foreign languages in UMS alongside seven other languages. In line with UMS' language goal via the Centre for the Promotion of Knowledge and Language Learning (CPKLL), the teaching of foreign language aims to produce learners who are able to communicate fluently in a second or third language. 
One of the pre-requisites of any foreign language course in UMS is that a learner must not be of the ethnic group who speaks the language. Apart from that, the learner must also be a total beginner, which means that he or she had never learned the language in school before that. Finally, learners who take foreign languages are seen as those who excelled in the Malaysian University English Test (MUET), of which they must have scored between Band 3 upper (cut off point: 159 points and above) to the highest Band 6.

Arabic is taken by Malaysian learners of various ethnicities including Malay, Chinese, Indians, native Sarawakians and native Sabahans including Kadazandusun. The focus of the current paper is the group of Kadazandusun learners. Thus, the paper is preliminary in nature, which is a comparative study on the features of Arabic and Kadazandusun, for the purpose of enabling the lecturer to test whether or not the findings on the differences of the languages are significant to affect the Kadazandusun learners' learning of Arabic. In this paper, the differences between some aspects of Arabic and Kadazandusun phonology and their pedagogical implications are discussed.

\section{Literature Review}

The study of Arabic in Malaysia has either one of the following purposes: 1. Religious purposes (Kamarul et al. 2009; Zainur \& Rosni, 2007). 2. Communicative purposes (Ab. Halim, 2006; Hassan Basri \& Mohammad Azhar, 2004). In UMS itself, the teaching of Arabic as a foreign language concerns communicative purposes only.

It is commonly believed that when adults start learning a second language, they are very often guided by their first language, especially at the level of phonology. This is usually referred to as a foreign accent. In the field of linguistics, this is referred to as first language (LI) transfer (Huthaily, 2003). Huthaily (2003) studies the phonological difficulties that adult native speakers of American English encounter while learning Modern Standard Arabic as a foreign language. The study focuses on describing the segmental phonemes of both Arabic and English and analyzes the Arabic speech of three American. He used the Contrastive Analysis Hypothesis (CAH) framework to predict the errors that adult English-speaking students of Arabic would make in their Arabic speech. The study found out that there was evidence that the subjects' first language had an effect on their production of speech sounds of the second language.

One of the most basic things when it comes to learning a language is the pronunciation. A contrastive analysis of Arabic and the mother tongue of the learners gives insights on the areas of learning difficulties. In terms of pronunciation, Issraq (2017) applied the Mahjub Phonetic Module to analyse the difficulties faced by form 4 learners in a school in Kota Kinabalu, in learning to pronounce the Arabic consonants, as well as to improve their pronunciation. His findings showed that the module was effective in helping the learners improve their pronunciations.

Nur Afifah (2012) conducted a study on the vowel pronunciation of Malay Arabic learners in a local public institution of higher learning. The findings revealed that the learners faced difficulties in pronouncing vowel articulations such as lengthening long vowels and shortening long vowels, replacing vowels or omitting vowels. These errors occurred both in the pronunciations of verbs and noun, but were more prominent in the pronunciations of nouns. Although errors occur in all words of two until six syllables, three syllable-words were more often mispronounced. 
INTERNATIONAL JOURNAL OF ACADEMIC RESEARCH IN BUSINESS AND SOCIAL SCIENCES

Vol. 9, No. 2, Feb, 2019, E-ISSN: 2222-6990 C 2019 HRMARS

\section{Objectives}

The study was conducted with two objectives:

a) To see the differences between the phonological systems of Arabic and Kadazandusun

b) To suggest how the differences might be affecting learners of Kadazandusun who learn Arabic as a foreign language

\section{Methodology}

The theory guiding this study is Contrastive Analysis Hypothesis (CAH) which can be summarised following Gass and Selinker (1994: 96-97) as follows:

1. Contrastive analysis is based on a theory of language that claims that language is habit and that language learning involves the establishment of a new set of habits.

2. The major source of error in the production and/or reception of a second language is the native language.

3. One can account for errors by considering differences between the $\mathrm{LI}$ and the $\mathrm{L} 2$.

4. A corollary to \#3 the greater the differences, the more errors that will occur.

5. What one has to do in learning a second language is to learn the differences.

Similarities can be safely ignored as no new learning is involved. In other words, what is dissimilar between two languages is what must be learned.

6. Difficulty and ease in learning are determined respectively by differences and similarities between the two languages in contrast.

In particular, tenet \#5 is held on to for this paper. The authors listed all the Arabic and Kadazandusun consonant and vowels, and made a comparison table. The similarities and differences were then identified as will be presented in the next section.

\section{Findings}

This section presents the findings of the study. The first part discusses the vowels of Arabic and Kadazandusun, followed by a discussion of Arabic and Kadazandusun consonants, vowel functions, consonant functions, and finally predicted learning difficulties of Kadazandusun learners learning Arabic.

\section{The Vowels of Arabic and Kadazandusun}

According to Huthaily (2003) Arabic has the phonemes /a/, /a:/, /i/, /i:/, and /u/ and /u:/ (p.28-29). Arabic lacks the phoneme /o/ that Kadazandusun has. The table (1) below shows the six Arabic vowel phonemes with an example for each of them. 
INTERNATIONAL JOURNAL OF ACADEMIC RESEARCH IN BUSINESS AND SOCIAL SCIENCES

Vol. 9, No. 2, Feb, 2019, E-ISSN: $2222-6990$ ๑ 2019 HRMARS

Table (1): The Vowel Phonemes of Arabic

\begin{tabular}{|c|c|c|c|c|}
\hline \multirow[t]{2}{*}{ No } & \multirow[t]{2}{*}{ Vowels } & \multicolumn{3}{|c|}{ Examples } \\
\hline & & Arabic Word & Phonemic Transcription & Meaning \\
\hline 1 & ي - /i:/ & صِيْت & /s ${ }^{\varsigma} \mathrm{i}: \mathrm{t} /$ & Reputation \\
\hline 2 & - - /i/ & سِتِ & /sit/ & Six \\
\hline 3 & $g^{\prime}-/ u: /$ & صَوْمُم & $/ s^{s} u: t /$ & Fast (v.) \\
\hline 4 & $\dot{8}-/ \mathrm{u} /$ & صَمّم & $/ \mathrm{s}^{\varsigma} \mathrm{um} /$ & Deaf \\
\hline 5 & ىাঁ-/a:/ & مَالٌ & /ma:l/ & Money \\
\hline 6 & $-/ a /$ & مَلَّ & /mal/ & He got bored \\
\hline
\end{tabular}

In contrast to that, Kadazandusun has a simple vowel system which constitutes only /a/,/i/, /o/ and /u/. /o/ has two realisations which is / /and /ə/. Other vowels may be lengthened as a prosodic feature such as when a speaker is emphasizing sizes or distance. The table (2) below shows the four Kadazandusun vowel phonemes with an example for each of them.

Table (2): The Vowel Phonemes of Kadazandusun

\begin{tabular}{|c|c|c|c|c|}
\hline \multirow{2}{*}{ No } & \multirow{2}{*}{ Vowels } & \multicolumn{3}{|c|}{ Examples } \\
\cline { 3 - 5 } & & Kadazandusun & Phonemic Transcription & Meaning \\
\hline $\mathbf{1}$ & $\mathrm{a}-/ \mathrm{a} /$ & Akan & /akan/ & Eat (v) \\
\hline $\mathbf{2}$ & $\mathrm{i}-/ \mathrm{i} /$ & Inum & /inum/ & Drink (v) \\
\hline $\mathbf{3}$ & $\mathrm{o}-/ \mathrm{o} /$ & Osomok & /osomok/ & Open (v) \\
\hline $\mathbf{4}$ & $\mathrm{u}-/ \mathrm{u} /$ & Ukab & /ukab/ & \\
\hline
\end{tabular}

The Contrastive Analysis of Arabic and Kadazandusun Vowels

It is predicted that Kadazandusun learners may not face too much difficulty when learning the pronunciation of Arabic vowels as they share the same vowels. 
INTERNATIONAL JOURNAL OF ACADEMIC RESEARCH IN BUSINESS AND SOCIAL SCIENCES

Vol. 9, No. 2, Feb, 2019, E-ISSN: 222 2-6990 ㄷ 2019 HRMARS

The Consonants of Arabic and Kadazandusun

Arabic has 28 consonant phonemes, as opposed to 15 of Kadazandusun (Huthaily, 2003; Lasimbang \& Evon, 2010; Atin, 2017:1; Bahagian Pembangunan Kurikulum, 2008:3).

Table (3) below shows the 28 Arabic consonant phonemes with an example for each of them.

Table (3): The Consonant Phonemes of Arabic

\begin{tabular}{|c|c|c|c|c|}
\hline \multirow[t]{2}{*}{ No } & \multirow[t]{2}{*}{ Consonants } & \multicolumn{3}{|c|}{ Examples } \\
\hline & & Arabic Word & Phonemic Transcription & Meaning \\
\hline 1 & - - 1b/ & بَحْر & /baћr/ & sea $(n)$ \\
\hline 2 & ت-t/ & تَمْر & /tamr/ & dates $(n)$ \\
\hline 3 & $b-/ t^{c} /$ & طِيْنِ & $/ t^{\mathrm{c} i} \mathrm{i} n /$ & soil (n) \\
\hline 4 & $د-/ d /$ & دِيْن & /di:n/ & religion $(\mathrm{n})$ \\
\hline 5 & ض -/d / & رَضِينع & /rad ${ }^{\mathrm{c}} \mathrm{i}: \mathrm{S} /$ & infant $(n)$ \\
\hline 6 & s - $-/ \mathrm{k} /$ & كِتَاب & /kita:b/ & book (n) \\
\hline 7 & 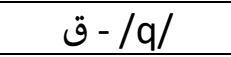 & قَويٌّيُ & /qawiyyun/ & strong (adj) \\
\hline 8 & $\leq-/\} /$ & أَسَسَد & /Pasad/ & $\operatorname{lion}(\mathrm{n})$ \\
\hline 9 & - - ف /f/ & فَرَس & /faras/ & horse (n) \\
\hline 10 & 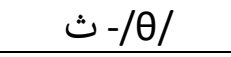 & ثَوْر & /Oawr/ & bull $(n)$ \\
\hline 11 & $\dot{j}-/$ / & ذُبَاب & /ðuba:b/ & flies (n) \\
\hline 12 & ظ-/ð؟/ & ظَرْف & /す`arf/ & envelope (n) \\
\hline 13 & - /s/ & سُرُوْر & /suru:r/ & happiness (n) \\
\hline 14 & $ص-/ s^{s} /$ & صِفْر & /s'ifr/ & zero (n) \\
\hline 15 & $j-/ z /$ & زَائرِ & /za:Pir/ & visitor (n) \\
\hline 16 & ا & شَمْس & /Jams/ & $\operatorname{sun}(n)$ \\
\hline 17 & ج-/d/ & جُرْح & /dzurh/ & wound (n) \\
\hline 18 & $\dot{\tau}-/ x /$ & خِبْرَة & /xibrah/ & experience (n) \\
\hline 19 & $\dot{\varepsilon}-/ \gamma /$ & غَرِيْب & /yari:b/ & stranger $(n)$ \\
\hline 20 & $\tau-/ \hbar /$ & حُبَّ & /hubb/ & love (n) \\
\hline 21 & $\varepsilon-/ \varsigma /$ & عِيْد & /̧i:d/ & feast $(n)$ \\
\hline 22 & ه-/h/ & هَوَاء & /hawa:?/ & $\operatorname{sun}(n)$ \\
\hline 23 & م-/m/ & مَسْجِد & /masdzid/ & mosque $(n)$ \\
\hline 24 & $\dot{ن}-/ \mathrm{n} /$ & نَاعِم & /na:Sim/ & soft (n) \\
\hline 25 & J-/I/ & لَحْم & /laћm/ & meat $(\mathrm{n})$ \\
\hline 26 & $\mathrm{~J}-/ \mathrm{r} /$ & فِرَق & /firaq/ & groups (n) \\
\hline 27 & ي-y/ & كَمِيْنِن & /yami:n/ & right $(n)$ \\
\hline 28 & $9-/ w /$ & وَقْت & /waqt/ & time $(n)$ \\
\hline
\end{tabular}

Table (4) below shows the 15 Kadazandusun consonant phonemes with an example for each of them. The list is adopted from the Kadazandusun course module by Atin (2017), circulated in Universiti Malaysia Sabah (UMS). 
INTERNATIONAL JOURNAL OF ACADEMIC RESEARCH IN BUSINESS AND SOCIAL SCIENCES Vol. 9, No. 2, Feb, 2019, E-ISSN: $2222-6990$ ๑ 2019 HRMARS

Table (4): The Consonant Phonemes of Kadazandusun

\begin{tabular}{|c|c|c|c|c|}
\hline \multirow[t]{2}{*}{ No } & \multirow[t]{2}{*}{ Vowels } & \multicolumn{3}{|c|}{ Examples } \\
\hline & & Kadazandusun & Phonemic Transcription & Meaning \\
\hline 1 & $b-/ b /$ & Buuk & /bu:k/ & book (n) \\
\hline 2 & $d-/ d /$ & Duwo & /duwo/ & two (n) \\
\hline 3 & $g-/ g /$ & Gakod & /gakod/ & $\operatorname{leg}(n)$ \\
\hline 4 & $\mathrm{~h}-/ \mathrm{h} /$ & Huyas & /huyas/ & dismantle (v) \\
\hline 5 & $\mathrm{k}-/ \mathrm{k} /$ & Kokot & /kokot/ & bite (v) \\
\hline 6 & $1-/ / /$ & Luong & /luon/ & $\operatorname{corn}(n)$ \\
\hline 7 & $m-/ m /$ & Mata & /mata/ & raw, uncooked (adj) \\
\hline 8 & $n-/ n /$ & Nondui & /nondui/ & mosquito (n) \\
\hline 9 & $\mathrm{ng}-/ \mathrm{n} /$ & Ngaran & /naran/ & name $(\mathrm{n})$ \\
\hline 10 & $p-/ p /$ & Palad & /palad/ & palm [of hand] (n) \\
\hline 11 & $r-/ r /$ & Ragang & /ragan/ & red (adj) \\
\hline 12 & $s-/ s /$ & Sudai & /sudai/ & $\operatorname{comb}(\mathrm{n})$ \\
\hline 13 & $t-/ t /$ & Tukad & /tukad/ & ladder, stairs (n) \\
\hline 14 & $w-/ w /$ & Wogok & /wogok/ & pig $(n)$ \\
\hline 15 & $y-/ y /$ & Yopos & /yopos/ & wet (adj) \\
\hline
\end{tabular}

Some Kadazandusun consonant phonemes are not listed above as the Kadazandusun course module of UMS does not cover them. In addition to the set above, Miller (1993:8) argued the phoneme $\mathrm{j}-/ \mathrm{d} / \mathrm{b} /$ is borrowed from Malay but is only used in loanwords, such as /dzam/ - 'hour'. Furthermore, the phoneme c - / $\mathrm{f} /$ (katfan-"peanut"), $f$ - /f/ (feri-"ferry"), q -/q/ (quran) and $x$ - / $x /$ ( $x$ ray) are used for loanwords (Robinson, 2005:9; Jiminit, 2015; Bahagian Pembangunan Kurikulum, 2008).

Moreover, the set of phonemes that this current study follows, does not have the consonant [?], known as sigot ['] that is used for certain grammatical functions such as to differentiate the meanings between two words (eg: boli" "male pig" and boli“buy") (Atin, 2017; Bahagian Pembangunan Kurikulum, 2008). However Robinson, (2005), Jiminit (2015) and Price (2007) list it among the Kadazandusun consonants.

On the other hands, Bahagian Pembangunan Kurikulum (2008) treats ng - [ $\eta$ ] merely as a nasal sound (songui) that is pronounced when $[\mathrm{n}]$ and $[\mathrm{g}]$ come together as a unit, without including it as part of Kadazandusun consonant. In contrast to that, Atin (2017) considers it as part of Kadazandusun consonants.

Apart from that, /v/ - vogok "pig" and /z/ - zadaan "rejected" are sounds that are prominent in the Coastal Kadazan dialect (Penampang, Papar) and Rungus (Kudat). Most of the time these sounds are the variants of /w/ and / $y /$ in Central Dusun (Bundu/Liwan) (Atin, 2017). The current study only focuses on Kadazandusun Bunduliwan, which is based on the Central Dialect. Thus both/v/ and / $z$ / are not included in the list. 


\section{The contrastive analysis of Arabic and Kadazandusun consonants}

The list below shows the results after carrying out the contrastive analysis of Kadazandusun and Arabic consonants:

i. Arabic has the phonemes /b/ and /f/, while Kadazandusun only has the phoneme /b/.

ii. Arabic has the phonemes $/ \mathrm{t} /$ and $/ \mathrm{t}^{\varsigma} /$, but Kadazandusun only has the phoneme $/ \mathrm{t} /$.

iii. Arabic has the phonemes $/ d /$ and $/ d^{\varsigma} /$, while Kadazandusun only has the phoneme $/ d /$.

iv. Arabic has the phonemes $/ \mathrm{s} /, / \mathrm{s}^{\mathrm{s}} /, / \theta /$ and $/ \mathrm{J} /$, and Kadazandusun only has the phoneme $/ \mathrm{s} /$.

v. Arabic has the phoneme $/ \mathrm{h} /$ and $/ \mathrm{h} /$, but Kadazandusun only has the phoneme $/ \mathrm{h} /$.

vi. Arabic has the phoneme $/ \mathrm{d} / /, / z /, / \delta /$ and $/ \delta \varsigma /$, while Kadazandusun merely has nothing like the four Arabic consonants.

vii. Arabic has the phonemes $/ \mathrm{R} /$ and $/ \varsigma /$, and Kadazandusun only has the phoneme $/ \mathrm{R} /$.

viii. Arabic has the phonemes $/ \mathrm{k} /$ and $/ \mathrm{q} /$, and Kadazandusun only has the phoneme $/ \mathrm{k} /$.

ix. Arabic has the phonemes $/ \mathrm{y} /$ and $/ \mathrm{x} /$, but Kadazandusun does not have both of them.

$\mathrm{x}$. Arabic and Kadazandusun share the phonemes $/ \mathrm{r} /, / \mathrm{l} /, / \mathrm{n} /, / \mathrm{m} /, / \mathrm{y} /$ and $/ \mathrm{w} /$.

\section{The differences between Arabic and Kadazandusun in terms of grammatical function carried by} the vowels

The Arabic vowels are used in nouns and adjectives to alter their meanings in terms of plurality

Morphophonologically, the long vowels are added to nouns and adjectives to indicate plurality ('Abbas, 1995);

i. Long vowel Iি- /a:/ of the suffix a noun or adjective to form the nominative dual form, as in the following example:

/at.ta:.li.ba:.ni/ "the two male students"

ii. Long vowel İ - /a:/ of the suffix plural entities) in the nominative case. The suffix is used to pluralise feminine nouns and adjectives ending in $\tau_{0}-a$. Apart from that, it is also used to pluralise non-human nouns. For example:

$$
\text { - /at.ta:.li.ba:.t/ "the female students (more than two persons)" }
$$

iii. Long vowel ي-/i:/ of the suffix يْ _- ina, is a mark of jama' al-Muzakar as-Sālim (masculine plural entities) in both the accusative case and genitive case.

For instance:

$$
\text { - الطالبِيننَ /at.ta:.li.bị..na/ "the male students (more than two persons)" }
$$

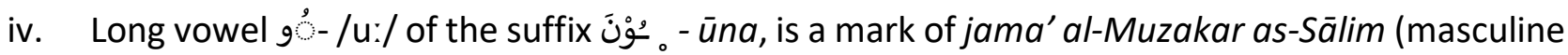
plural entities). This nominative-case suffix is used to pluralise masculine nouns and adjectives referring to people.

For example:

الطالبُوْنَ - /at.ta:.li.buي..na/ "the male students (more than two persons)" 
The same cannot be said for Kadazandusun as it has its own way to express plurality of nouns. Kadazandusun nouns possess a small set of morphemes that can be used to alter their meanings: son- to express singularity, $\boldsymbol{k} \boldsymbol{i}$ - to express ownership and <ongo> to express plurality. Nouns with attached morphemes still act like simple nouns, so they can still be used as normal within noun phrases (Price, 2007:34).

The Arabic vowels are used in verbs to modify the subject in terms of person, gender and plurality

The long vowels play an important role in Arabic verb conjugation. In Arabic, the subject pronoun is frequently dropped. The subject (namely the one doing the verb) can be identified from the verb conjugation, so it is not necessary to use the subject pronoun in such cases except for emphasis. When conjugating verbs with the long vowel /a:/, /u:/ and /i:/, the subject will be characterised into either one of these three; 1. type of pronoun (first, second and third person), 2. gender (masculine and feminine) and 3. plurality (singular, dual and plural) (Zaki \& Radiah, 2010).

i. The long vowel /a:/ that occurs word-finally in a past tense indicates the subject as a third person, masculine and dual. For instance, the long vowel 10-/a:/ conjugates the verb in the sentence قَّامَ-/qa:.ma:/ "two men stood up".

ii. The long vowel /u:/ that occurs word-medially in an imperative verb, indicates that the subject is a third person, masculine and plural. For instance, the long vowel g-/u:/ conjugates

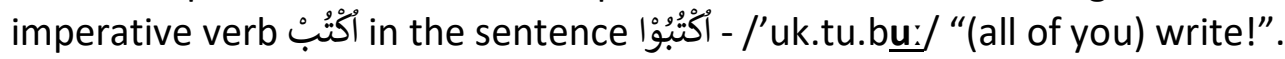

iii. The long vowel /i:/ that occurs word-finally in an imperative verb, indicates the subject as a second person, feminine and singular. For instance, the long vowel s-/i:/ conjugates the

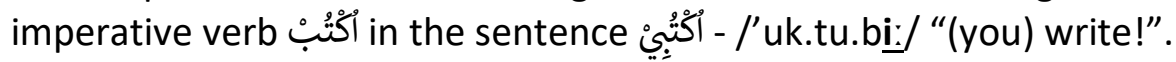

None of these phenomena exists in Kadazandusun, which provides us with the insights of possible learning difficulties of the learners as will be discussed in the later section.

\section{The Arabic vowelsare used in nouns to determine the grammatical case system}

The short vowels play a significant role in upholding the Arabic case system (الإعراب). The vowels come as little markings that are attached to the ends of words to indicate the words' grammatical function (Zaki \& Radiah, 2010). For example;

i. The short vowel /a/ above a consonant that occurs word-finally, indicates accusative case (حالة النصب) of a noun used as an object in verbal sentence, as in the following example:

raa'itu AI-I'mraa'ta allati tatakallam Al-I'njilīziy

I saw the woman who speaks the English

"I saw the woman who speaks English"

ii. The short vowel /i/ below a consonant that occurs word-finally, indicates genitive case ( حالة (الجرّ ) of a noun used as an object of preposition, locative adverb oras a second term of $i \not \bar{a} f a$, as the following example:

Ana katabtu Al-Darsbi Al-Qalami

I wrote the lesson with the pen

"I wrote the lesson with a pen" 
INTERNATIONAL JOURNAL OF ACADEMIC RESEARCH IN BUSINESS AND SOCIAL SCIENCES

Vol. 9, No. 2, Feb, 2019, E-ISSN: 2222-6990 C 2019 HRMARS

iii. The short vowel / $\mathrm{u} /$ above a consonant that occurs word-finally, can indicate nominative case (حالة الرفع) of a noun, used as a subject and predicate of a nominal sentence and a subject of a verbal sentence, as shown by the following example:

Huwa At-Tālibu

$\mathrm{He}$ is the male student

"He is the male student"

As opposed to that, vowels do not indicate grammatical cases at all in Kadazandusun.

\section{How the differences of the Vowel and Consonantal system might be affecting learners of Kadazandusun who learn Arabic as a foreign language}

Table (5): The Comparison of Vowel Phonemes between Arabic and Kadazandusun

\begin{tabular}{|c|c|}
\hline Arabic Vowels & Kadazandusun Vowels \\
\hline /i/,/i:/,/u/,/u:/,/a/,/a:/ & /i/,/u/,/a/,/o/ \\
\hline
\end{tabular}

In table (5) above, even though Kadazandusun has one extra different vowel compared to Arabic, and learners of Kadazandusun origin are not expected to have any difficulty pronouncing Arabic vowels, it is expected that they might have difficulties mastering the grammatical functions of Arabic indicated by the vowels. Those are plurality, subject modification with regards to person, gender, and plurality, as well as grammatical cases.

Table (6): The Comparison of Consonant Phonemes between Arabic and Kadazandusun

\begin{tabular}{|c|c|}
\hline Arabic Consonants & Kadazandusun Consonants \\
\hline$/ \mathrm{f} /$ & $/ \mathrm{p} /$ \\
\hline$/ \mathrm{t} /, / \mathrm{t}^{\mathrm{c}} /$ & $/ \mathrm{t} /$ \\
\hline$/ \mathrm{d} /, / \mathrm{d}^{\mathrm{c}} /$ & $/ \mathrm{d} /$ \\
\hline$/ \mathrm{h} /, / \mathrm{h} /$ & $/ \mathrm{h} /$ \\
\hline$/ \mathrm{k} /, / \mathrm{q} /$ & $/ \mathrm{k} /$ \\
\hline$/ \mathrm{r} /, / \mathrm{q} /$ & - \\
\hline$/ \mathrm{\gamma} /, / \mathrm{x} /$ & - \\
\hline$/ \mathrm{s} /, / \theta /, / \mathrm{s}^{\mathrm{c}} /, / \mathrm{s} /$ & $/ \mathrm{s} /$ \\
\hline$/ \mathrm{d} /, / \mathrm{z} /, / \delta /, / \mathrm{d}^{\mathrm{c}} /$ & - \\
\hline \multicolumn{2}{|c|}{$/ \mathrm{b} /, / \mathrm{r} /, / \mathrm{l} /, / \mathrm{n} /, / \mathrm{m} /, / \mathrm{y} /, / \mathrm{w} /$} \\
\hline
\end{tabular}

The Kadazandusun learners are expected to face numerous problems in recognizing and pronouncing certain sounds of Arabic consonantsas predicted below:

1. Having no /f/ sound in their language, the Kadazandusun learners are expected to unintentionally pronounce $/ f /$ as $/ p /$ due to the failure in mastering the place of articulation and the method of producing new letters that they do not encounter in their mother tongue. 
2. Arabic has the phonemes $/ t /$ and $/ t^{\varsigma} /$, but Kadazandusun only has the phoneme $/ t /$. The expected area of difficulty is how to produce the correct sound of the phoneme $/ t^{\varsigma} /$.

3. Similarly, Arabic has the phonemes $/ d /$ and $/ d^{\varsigma} /$, and yet Kadazandusun only has the phoneme /d/. Expected area of difficulty is how to produce the correct sound of the phoneme $/ d^{\varsigma} /$.

4. Kadazandusun learners may find the sounds of the phonemes $/ \theta /, / s^{\varsigma} /$ and $/ \delta /$ to be totally different from $/ \mathrm{s} /$, and they might find it difficult to pronounce $/ \theta /, / \mathrm{s}^{\mathrm{s}} /$ and $/ \mathrm{J} /$. As a result, most of the times they would tend to accidentally pronounce them as $/ \mathrm{s} /$ due to the influence from their mother tongue.

5. Arabic has the phonemes $/ \mathrm{h} /$ and $/ \hbar /$, but Kadazandusun only has the phoneme $/ \mathrm{h} /$. It is expected that pronouncing $/ \mathrm{h} /$ will be another area of difficulty for the Kadazandusun speakers as it has almost identical sound with $/ \mathrm{h} /$. They may mispronounce $/ \mathrm{h} / \mathrm{as} / \mathrm{h} /$.

6. Arabic has the phonemes $/ \mathrm{d} /, / \mathrm{z} /, / \delta /$ and $/ \delta \varsigma /$, while Kadazandusun does not have any of them.The expected area of difficulty is in pronouncing the phonemes $/ \delta /$ and $/ \delta^{\varsigma} /$ excluding /dz/ and /z/. Some Kadazandusun speakers (especially Central Dusun speakers) might not face any difficulty in pronouncing the phoneme $/ d_{3} /$ as it is used in loan words (Miller, 1993). Otherwise, they might generally pronounce the phonemes $/ z /, / \delta /$ and $/ ð \varsigma /$ as $/ d_{b} /$ due to the fact that it is easier to pronounce and has a closer sound to those three phonemes. On the other hand, some Kadazandusun speakers (especially Coastal Kadazan speakers) are very familiar with the phoneme / $z$; thus they would not experience difficulties in pronouncing it (Atin, 2017).

7. Arabic has the phonemes $/ \mathrm{R} /$ and $/ \varsigma /$, and Kadazandusun only has the phoneme $/ ? /$. Due to the fact, the expected area of difficulty is in pronouncing / $/$. The kadazandusun speakers might find the sound of the both phonemes to be very different, and face a hard time to pronounce $/ \varsigma /$ correctly. They are most likely to produce the sound / $/$ / when trying to pronounce $/ \varsigma /$.

8. Arabic has the phonemes $/ y /$ and $/ x /$, but Kadazandusun has neither of them. Naturally, the expected area of difficulty would be $/ \gamma /$ and $/ x /$. The sounds of the phonemes $/ \gamma /$ and $/ x /$ would be totally alien in the phonetical system of Kadazandusun. As a result, Kadazandusun learners might produce $/ \mathrm{g} /$ instead of $/ \mathrm{y} /$ and $/ \mathrm{h} /$ instead of $/ \mathrm{x} /$ due to the fact that their sounds are close to one another.

9. Arabic has the phonemes $/ \mathrm{k} /$ and $/ \mathrm{q} /$, and Kadazandusun only has the phoneme $/ \mathrm{k} /$. The probability of the Kadazandusun studentsmispronouncing the phonemes /q/ as /k/ is very high, even though the phoneme $/ q /$ is also used for loan word nowadays (Jiminit, 2015:10).

10. Finally, learning how to pronounce the phonemes/b/, /r/, /l/, /n/, /m/, /y/ and /w/ properly would be really easy as both Arabic and Kadazandusun share those same phonemes.

The results above clearly show how a mother tongue influence takes place in the process of learning Arabic. The sound pattern of the learner's first language is transferred into the second language and is likely to cause foreign accents, and that obviously applies on all nine Arabic consonants that are difficult to be pronounced properly by Kadazandusun speaker, which are $\tau-/ \hbar /$,

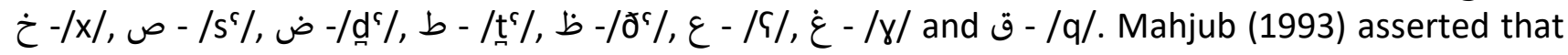
most of the non-native speakers find it is difficult to pronounce those nine Arabic consonants. 
In this respect, Avery and Ehrlich (1992) point out that the sound system of the native language can influence the learners' pronunciation of a target language in at least three ways. First, when there is a sound in the target language which is absent from the learners' native sound inventory, or vice versa,learners may not be able to produce or even perceive the sound(s). Second, when the rules of combining sounds into words (i.e., phonotactic constraints/rules) are different in the learners' mother tongue from those of the target language, they cause problems for learners because these rules are language specific as they vary from one language to another. Thirdly, since the rhythm and melody of a language determine its patterns of stress and intonation, learners may transfer these patterns into the target language.

Despite all of the differences, difficulties faced by Kadazandusun learners who are learning Arabic differ from one to another according to the dialect that the learner speaks and the degree of exposure to the Arabic language that he or she is having with (Shively, 2008).

\section{Conclusion}

In conclusion, the current research indicates that generally the sound systems of Kadazandusun and Arabic share three similar vowels, but Arabic has twelve consonants that are different than Kadazandusun. Furthermore, Arabic vowel alterations can carry grammatical functions such as plurality which do not exist in Kadazandusun.

Having discovered all of the differences in the sound systems of Kadazandusun and Arabic, the teachers of Arabic who would be teaching the language to the group of Kadazandusun learners will be more prepared to device lessons and approaches to teach pronunciations more effectively. It is suggested that the teachers first test the pronunciations of the Kadazandusun learners to see if all of the predictions above are correct.

Secondly, the teachers can eliminate wrong assumptions and start working on improving on the problematic areas such as on making students master the grammatical functions carried by the vowels and nouns.

Thirdly, the teachers may want to focus on their approaches of teaching pronunciation and communication inorder to help the learners master Arabic more effectively. This is very important not only for the purpose of communication, but also in motivating the learners to enjoy learning Arabic as their second or third language.

Last but not least, researches are meant for contribution theoretically and contextually. The current research is considered as a progressive effort toward promoting the comparative study between Arabic and Kadazandusun language especially among Malaysian researchers, as it is among the pioneers of the research area. Thus, its findings are expected to benefit the stakeholders at large. For instance, the findings would provide lecturers and teachers with a solid foundation and the best formula in designing, theoretically and contextually, an effective way of teaching Arabic language to the Kadazandusun learners whom are pursuing their bachelor's degree in Universiti Malaysia Sabah (UMS). 
INTERNATIONAL JOURNAL OF ACADEMIC RESEARCH IN BUSINESS AND SOCIAL SCIENCES

Vol. 9, No. 2, Feb, 2019, E-ISSN: 2222-6990 C 2019 HRMARS

\section{References}

'Abbas, H. (1995). Al-Naḥw al-Waāfĩ. Edisi Kesebelas. Kaherah: Dār al-Ma'ārif.

Ab. Halim, I. (2005). Pengajaran bahasa Arab melalui kaedah komunikatif. In Hassan Basri Awang Mat Dahan, Zawawi Ismail \& Muhammad Azhar Zailani. (pnyt.). Pendidikan Islam dan bahasa Arab: Perspektif Pengajian Tinggi. Kuala Lumpur: Penerbit Universiti Malaya.

Avery, P. and Ehrlich, S. (1992), Teaching American English Pronunciation. Oxford: Oxford University Press.

Puralan Boros Kadazandusun id Sikul. (2008). Kuala Lumpur: Kementerian Pelajaran Malaysia.

Price, D. C. (2007). Bundu Dusun Sketch Grammar. Unpublished manuscript.

Retrieved from http://blog.thetelegraphic.com/wp-content/uploads/2008/12/bundu-dusunsketch-grammar.pdf

Hago, O. \& Khan, W. (2015). The Pronunciation Problems Faced by Saudi EFL Learners at

Secondary Schools. Education and Linguistics Research, 1(2), 85-99. Retrieved from http://doi.org/10.5296/10.5296/elr.v1i2.7783

Issraq, R. (2017). Aplikasi Teori Mahjub dalam Memperbaiki Penyebutan Bunyi Bahasa

Arab dalam Kalangan Pelajar Sabah. Tesis PhD, Fakulti Bahasa dan Linguistik. Kuala Lumpur:

Universiti Malaya.

Jiminit, J. (2015). Fonotik om Fonologi Do Boros Kadazandusun. IPG Kent Tuaran.

Kamarul Shukri M. T., Mohamed Amin, E., Nik Mohd Rahimi N. Y. \& Zamri, M. (2009). Strategi metafizik: Kesinambungan penerokaan domain strategi utama pembelajaran bahasa, GEMA Online Journal of Language Studies 9 (2): 1-13.

Khaled, H. (2003). Contrastive Phonological Analysis of Arabic and English.

Dissertation presented in partial fulfilment for the requirements for the degree of Master of Art, The University of Montana. Retrieved from https://scholarworks.umt.edu/cgi/viewcontent.cgi?article=9145\&context=etd

Mohd Zaki, A. R. \& Che Radiah, M. (2010). Ciri -Ciri Bahasa Arab : Fonetik, Morfologi dan Sintaksis. Serdang: Penerbit Universiti Putra Malaysia.

Mahjub, A. F. (1993). Ta'lim wa Ta'allum al-Aswat al-'Arabiyyatal-Sa'bat Li Ghair alNatiqin Biha, Lil Mu'allim Wa al-Muta'allim. Al-Tab'at al-Thaniat..Ma'ahad al-Lughat al'Arabiyyat. Universiti Umm al-Qura.

Miller, C. (1993). Kadazan /Dusun phonology revisited. In A trilingual phrase book: Dusun Bundu' - Bahasa Malaysia-English, ed. by John and Carolyn Miller, 1-14. Kota Kinabalu: Sabah Museum.

Handbook of the International Phonetic Association: A Guide to the use of the International

Phonetic Association. (1999). Cambridge University Press. Retrieved from https://books.google.com.my/books?id=33BSkFV_8PEC\&printsec=frontcover\&dq=Handboo $\mathrm{k}+\mathrm{of}+$ the+International+Phonetic+Association\&hl=zh-

TW\&ei=2zzsTeWWHYeevgOrupi_Dw\&sa=X\&oi=book_result\&ct=result\&redir_esc=y\#v=onep age \&q\&f=false

Nur Afifah, M. A. Z. (2012).Masalah Sebutan Bunyi Vokal Bahasa Arab 
INTERNATIONAL JOURNAL OF ACADEMIC RESEARCH IN BUSINESS AND SOCIAL SCIENCES

Vol. 9, No. 2, Feb, 2019, E-ISSN: 2222-6990 C 2019 HRMARS

Dalam Kalangan Pelajar Melayu di IPTA. Tesis Master, Fakulti Bahasa dan Linguistik. Kuala Lumpur: Universiti Malaya. Retrived from http://studentsrepo.um.edu.my/5396/1/MASALAH_SEBUTAN_BUNYI_VOKAL_BAHASA_ARAB _DALAM_KALANGAN_PELAJAR_MELAYU_DI_IPTA.pdf

Lasimbang, R \& Evon, E. (2010). Rujukan Ringkas Aspek Linguistik Bahasa Kadazandusun. Kota Kinabalu: Kandavai Books.

Robinson, L.C. (2005). A sketch grammar of Tindal Dusun. University of Hawai'i Working Papers in Linguistics 36 (5):1-31.

Shively, R. L. (2008). L2 acquisition of $[\beta],[\delta]$, and $[\gamma]$ in Spanish: Impact of experience, linguistic environmentand learner variables. Southwest Journal of Linguistics, 27 (2), 79-114.

Susan M. Gass \& Lary, S. (1994). Second Language Acquisition, an Introductory Course. New York: Routledge. Retrieved from https://blogs.umass.edu/moiry/files/2015/08/Gass.Second-Language-Acquisition.pdf

Thelwall, R. (1990). Illustrations of the IPA: Arabic, Journal of the International Phonetic Association, 20 (2): 37-41, doi:10.1017/S0025100300004266

Atin, V. P. (2017). UD00102 Kadazandusun Level 1: Course Modul. Unpublished.

Zainur Rijal, A. R. \& Rosni, S. (2007). Kesan Bahasa Arab dalamPeradabanMelayu di Malaysia. Negeri Sembilan: Kolej Universiti Islam Malaysia. 